\title{
Identifying, Exploring and Verifying Resilient Grading System for Parks under the Disaster Context of Floods and Winds
}

\author{
Hao-Zhang Pan ${ }^{1}$, Sheng-Jung $\mathrm{Ou}^{2, *}$ \\ ${ }^{1}$ Department of Landscape and Urban Design, Chaoyang University of Technology, No 168, Jifeng E. Rd, Wufeng District, Taichung, \\ 41349, Taiwan, haozhangpan@gmail.com \\ ${ }^{2}$ Professor, Department of Landscape and Urban Design, Chaoyang University of Technology, No. 168, Jifeng E. Rd, Wufeng District, \\ Taichung, 41349, Taiwan, sjou@cyut.edu.tw
}

\begin{abstract}
In our living environment, we frequently encounter natural disasters such as typhoons, floods, earthquakes, drought, petrochemical plant safety accident, stripping accident and so on. Due to global climate change, natural disasters have become even more devastating. Thus, it is important to look for ways to mitigate disasters. This study employs the concept of resilience to examine the ability of parks to recover from natural disasters. According to previous disaster history, the damage caused by natural disasters in the parks is mainly water and wind. Therefore, this study first conducted a literature review to find out relevant resilience criteria that are advantageous for combating water and wind disasters, and to recognize the degree of resilience achieved by each criterion. Then, based on the elements of the resilience criteria, the study establishes a preliminary resilience grading system. Furthermore, three different types of parks are evaluated under the grading system. This study provides a theoretical basis for resilience grading and suggestions for improving parks in the future.
\end{abstract}

\section{Introduction}

In order to deal with various climate disasters, global warming and other problems, relevant scholars, scientists, and city planners conduct researches and discuss important issues such as resilient cities, resilient landscapes, and disaster prevention parks. Nowadays there are increasing numbers of cases to study and address issues in cities from the perspective of resilience. Resilient cities span a wide range from a global perspective to a community perspective. Therefore, facing the complex urban problems, we can analyze problems from many aspects and perspectives and use the most feasible and reasonable way to solve the problem. In this paper, we attempt to study the resilient city from park scale.

Up to day, the concept of resilient park has been mentioned to the public. However, its definition and evaluation criteria are still unclear. After the index screening, we find that the index system also contains social, economic, institutional, natural and other aspects. For the convenient use in the future when evaluating if the park is resilient enough, the study only focuses on the scope of the natural environment.

According to previous disaster history, disasters mainly cause flood and wind disasters to parks. Therefore, it is necessary to find the relevant resilience standard of natural element under the prevention and control of flood and wind disasters. To facilitate the subsequent estabDlishment of the resilient grading system, the natural elements, related to water disasters, enumerated in this study are grassy ditches, soils, paving, planting, and flood detention ponds. Natural elements related to wind disasters include wind-resistant tree species, configuration of multilayer planting, volume density of soil, and effects of wind speed.

After establishing the resilient grading system, three different types of parks were evaluated, namely Caohu Park, Nanyuan Park, and Taichung Park in Taichung City, Taiwan. The purpose of investigating these three different types of parks is to verify and find out the difference of resilience among disaster prevention parks, community parks and large parks. Which type of park is more resilient to floods and winds? Which type of park has the lowest resilience? From the final resilient grading, we can suggest what future projects need to be done in the park to strengthen their resilience.

Based upon the afore-mentions, the study proposes three research objectives listed as followings.

1. Identifying the key factors for preventing and controlling flood and wind disasters.

2. Exploring the resilient criteria for each natural element in the context of floods and winds.

3. Verifying the resilient grading system by using different types of park.

\section{Literature Review}

Corresponding author: sjou@cyut.edu.tw 


\subsection{Resilient standards for flood control}

Based upon the studies of Smith (2000)[1], Carsel \& Parrish (1988)[2], Zhaorui et al. (2019)[3], Tian (2018)[4], the resilient standards related to the water content and drainage velocity of various types of soil can be extracted. Their results reveal that the average saturated water content of loam and sandy loam is high, and soils of sandy loam and loam have faster drainage. Therefore, this study chooses soil with fast drainage and strong water storage capacity to arrange the soil resilient level. Considering soil type and the percentage of soil area in the park which is divided into four categories, the study generates the soil grading matrix as shown in Table 1 .

Table 1. Gading level for soil.

\begin{tabular}{|c|c|c|c|c|c|}
\hline Grade & $\begin{array}{c}\text { Soil / Percentage of } \\
\text { soil area in the base }\end{array}$ & $\mathbf{1 0 0 \%} \sim \mathbf{7 6} \%$ & $\mathbf{7 5 \%} \sim \mathbf{5 1} \%$ & $\mathbf{5 0} \mathbf{2} \mathbf{2 6} \%$ & $\mathbf{2 5 \%} \sim \mathbf{0} \%$ \\
\hline A & Poorly graded gravel & 5 & 5 & 4 & 4 \\
\hline A & Well graded gravel & 5 & 5 & 4 & 4 \\
\hline A & Argillaceous gravel & 5 & 5 & 4 & 4 \\
\hline A & Clayey gravel & 5 & 4 & 3 & 3 \\
\hline B & Sand & 4 & 4 & 3 & 3 \\
\hline B & Loamy sand & 4 & 4 & 3 & 3 \\
\hline B & Sandy loam & 4 & 4 & 3 & 3 \\
\hline B & Loam & 4 & 3 & 3 & 2 \\
\hline B & Poorly graded sand & 4 & 3 & 3 & 2 \\
\hline B & Well graded sand & 4 & 3 & 3 & 2 \\
\hline B & Argillaceous sand & 3 & 3 & 2 & 2 \\
\hline B & Clayey sand & 3 & 3 & 2 & 2 \\
\hline B & Silty sand & 3 & 3 & 2 & 2 \\
\hline B & Silt loam & 3 & 2 & 2 & 1 \\
\hline C & Silty clay loam & 2 & 2 & 1 & 1 \\
\hline C & Sandy clay & 2 & 2 & 1 & 1 \\
\hline C & Silty clay & 2 & 2 & 1 & 1 \\
\hline C & Clay & 2 & 2 & 1 & 1 \\
\hline C & Argillaceous clay & 2 & 2 & 1 & 1 \\
\hline C & Very fine sand & 2 & 1 & 1 & 0 \\
\hline C & Silt & 2 & 1 & 1 & 0 \\
\hline C & Sandstone & 1 & 1 & 0 & 0 \\
\hline C & Limestone & 1 & 1 & 0 & 0 \\
\hline & & & & & \\
\hline
\end{tabular}

Other than soil, the degree of resilience is also correlated with surface material used in the park. Baiyingfang (2017) [5], Alexander et al. (2019)[6] studied the proportion of hard pavement and grass in disaster prevention parks, and the proportion of permeable area to impervious area in the park. They proposed that more than $40 \%$ of square paving or lawn space that can be used as disaster prevention and evacuation should be provided. The park must have 56\% impervious area and $44 \%$ pervious area.

Considering the percentage of permeable area and grass area in the park which both are divided into three categories, the study generates the proportion of lawn and permeable area matrix as shown in Table 2.

Table 2.Grading level for lawn area and permeable area.

\begin{tabular}{|c|c|c|c|c|}
\hline Grade & $\begin{array}{c}\text { Permeable area/ } \\
\text { Lawn space }\end{array}$ & $\mathbf{>} \mathbf{4 0 \%}$ & $\mathbf{4 0 \%}$ & $<\mathbf{4 0 \%}$ \\
\hline A & $>44 \%$ & 5 & 4 & 3 \\
\hline B & $44 \%$ & 4 & 3 & 2 \\
\hline C & $<44 \%$ & 2 & 1 & 1 \\
\hline
\end{tabular}

In addition to the proportion of lawn and permeable area, Alam et al. (2019)[7] studied various types of permeable pavement. They concluded that interlocking brick concrete with low density aggregate is more conducive to drainage than dense compacted gravel limestone. Gravel interlocking block has high permeability and gravel has strong water storage capacity. Permeable asphalt can be used as road paving. Considering the permeable pavement material and the percentage of such pavement in the park which is divided into four categories, the study generates the permeable grading matrix as shown in Table 3 .

Table 3.Grading level for permeable pavement.

\begin{tabular}{|c|c|c|c|c|c|}
\hline Grade & $\begin{array}{l}\text { Permeable pavement / } \\
\text { Percentage of such pavement } \\
\text { in the base }\end{array}$ & $\begin{array}{l}\text { More than } \\
16 \%\end{array}$ & $15 \% \sim 11 \%$ & $10 \%-6 \%$ & Below 5\% \\
\hline A & Pervious asphalt & 5 & 5 & 4 & 4 \\
\hline A & Crushed stone & 5 & 5 & 4 & 3 \\
\hline A & Pea gravel interlocking block & 5 & 4 & 4 & 3 \\
\hline A & Permeable brick & 5 & 4 & 4 & 3 \\
\hline B & Porous concrete & 4 & 4 & 3 & 3 \\
\hline B & Graded aggregate & 4 & 3 & 3 & 2 \\
\hline B & $\begin{array}{l}\text { Interlocking block with sand as } \\
\text { joint filler }\end{array}$ & 3 & 2 & 2 & 1 \\
\hline $\mathrm{C}$ & Boulder & 2 & 2 & 1 & 1 \\
\hline $\mathrm{C}$ & $\begin{array}{l}\text { Construction method of } \\
\text { permeable brick (soft bottom) }\end{array}$ & 2 & 2 & 1 & 1 \\
\hline
\end{tabular}

Coners \& Leuschner (2005)[8] and Xibenye et al. (2018)[9] studied the influence of tree root thickness on water content, and the influence of deep root on water transpiration rate. They conclude that the finer the root system is, the greater the water content is. Deep-rooted trees are good for water transpiration. Considering the root thickness, root type, and water storage, the study establishes the grading matrix of planting root system type and planting root system water storage capacity as shown in Table 4 and table 5.

Table 4.Grading level for plant root type and root thickness.

\begin{tabular}{|c|c|c|c|c|}
\hline Grade & $\begin{array}{c}\text { Root thickness / } \\
\text { Root type }\end{array}$ & Deep roots & $\begin{array}{c}\text { Taproot } \\
\text { system }\end{array}$ & $\begin{array}{c}\text { Shallow root } \\
\text { system }\end{array}$ \\
\hline A & Fine & 4 & 3 & 2 \\
\hline B & Crude & 3 & 2 & 1 \\
\hline
\end{tabular}

Table 5. Grading level for root type and water storage capacity

\begin{tabular}{|c|c|c|c|c|}
\hline Grade & $\begin{array}{c}\text { Root type / } \\
\text { Storage capacity }\end{array}$ & More than $\mathbf{1} \mathbf{g}$ & $\mathbf{1} \mathbf{~ g} \sim \mathbf{0} \mathbf{g}$ & Below 0 g \\
\hline A & Deep roots & 5 & 4 & 3 \\
\hline B & Taproot system & 4 & 3 & 2 \\
\hline C & Shallow root system & 2 & 1 & 1 \\
\hline
\end{tabular}

The flood detention volume, flood detention area, flood detention height and other aspects are studied by the detailed plan (2014)[10] of Taichung City urban plan type B industrial zone. The results indicated that the design capacity of detention basin should be higher than the demand capacity, and the depth of detention basin should be at least $0.8 \mathrm{~m}$. Based upon these evidences, the study generated the flood detention area and detention height matrix as shown in Table 6. 
Table 6. Grading level for flood detention area and detention

\begin{tabular}{|c|c|c|c|c|}
\hline Grade & $\begin{array}{c}\text { Flood detention area / } \\
\text { Detention height }\end{array}$ & $\begin{array}{c}\text { More than } \\
\mathbf{1 m}\end{array}$ & $\mathbf{1 m} \sim \mathbf{0 . 8 m}$ & Below 0.8m \\
\hline A & More than 2100 square meters & 5 & 4 & 3 \\
\hline B & $2100 \sim 700$ square meters & 4 & 3 & 2 \\
\hline C & Below 700 square meters & 2 & 1 & 1 \\
\hline
\end{tabular}

\subsection{Resilient standards for wind control}

D'Amico et al. (2019)[11], Clatterbuck (2000)[12], and Dong et al. (2020)[13] studied the wind resistance of tree species. Their results reveal that trees with strong wind resistance show slight inclination of trunk and partial abscission of leaves in wind disaster. Dogwood has the highest survival rate during strong winds. The windresistant tree species selected in the future does not require frequent pruning. Based upon their findings, this study generated a matrix for different tree species as shown in Table 7.

Table 7. Grading level for wind resistance for different tree

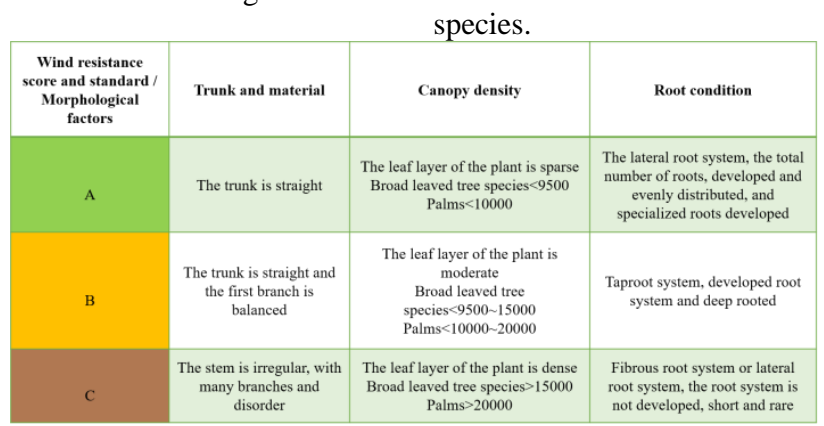

Head et al. (2001)[14] researched on the configuration of multi-layered plants, they conclude that the length or width of the trees should not be less than 7.6 meters, and the length or width of the shrubs should not be less than 3 meters. According their findings, this study creates a matrix for tree richness and tree group length as shown in Table 8 .

Table 8. Grading level for tree richness and tree group length.

\begin{tabular}{|c|c|c|c|c|}
\hline Grade & $\begin{array}{c}\text { Tree richness / } \\
\text { Tree group length }\end{array}$ & $\mathbf{> 7 . 6 m}$ & $\mathbf{7 . 6 m}$ & $<\mathbf{< . 6 m}$ \\
\hline A & Very rich & 5 & 5 & 4 \\
\hline A & Rich & 5 & 4 & 4 \\
\hline B & Ordinary & 4 & 3 & 3 \\
\hline C & Not rich & 3 & 2 & 2 \\
\hline C & Not very rich & 2 & 1 & 1 \\
\hline
\end{tabular}

\begin{tabular}{|c|c|c|c|c|}
\hline Grade & $\begin{array}{c}\text { Shrub richness / } \\
\text { Shrub length }\end{array}$ & $>\mathbf{3 m}$ & $\mathbf{3 m}$ & $<\mathbf{3 m}$ \\
\hline A & Very rich & 5 & 5 & 4 \\
\hline A & Rich & 5 & 4 & 4 \\
\hline B & Ordinary & 4 & 3 & 3 \\
\hline C & Not rich & 3 & 2 & 2 \\
\hline C & Not very rich & 2 & 1 & 1 \\
\hline
\end{tabular}

Quine et al. (1995)[15] studied soil types and soil bulk density. They conclude that peat soil can make plant root grow better and resist wind disaster. The ideal soil bulk density is between 1.0 and $1.7 \mathrm{mg} / \mathrm{m}^{-3}$, the volumetric water content is about $30 \%$, and the volumetric air content is about $20 \%$. Based upon their findings, this study generates a matrix for soil volume density as shown in Table 9.

Table 9. Grading level for soil volume density.

\begin{tabular}{|c|c|c|c|c|c|c|}
\hline Grade & $\begin{array}{c}\text { Soil permeability / } \\
\text { Soil compactness }\end{array}$ & Very close & Tight & Ordinary & Loose & $\begin{array}{c}\text { Relatively } \\
\text { loose }\end{array}$ \\
\hline A & Very breathable & 5 & 5 & 5 & 4 & 4 \\
\hline A & Quite breathable & 5 & 5 & 4 & 3 & 3 \\
\hline B & Ordinary & 4 & 4 & 4 & 3 & 3 \\
\hline C & Airtight & 3 & 3 & 3 & 2 & 2 \\
\hline C & Very airtight & 2 & 2 & 2 & 1 & 1 \\
\hline
\end{tabular}

\section{Resilience evaluation results for three different parks}

\subsection{Caohu Park}

Soil grade score: loam is the main soil in the park, as well as gravel, sandy loam and loamy sand. The lack of maintenance in the park has led to a lot of soil hardening. The final grade is: B.

Grade score of lawn area and permeable area: except the flood detention pool is impermeable pavement in the park, the rest are permeable bricks. The final grade is: A.

Grade score of permeable pavement: nearly half of the pavement in the park is permeable brick, and the lower layer of permeable brick has good water storage system. The final grade is: A. Figure 1 shows permeable pavements in Caohu Park.

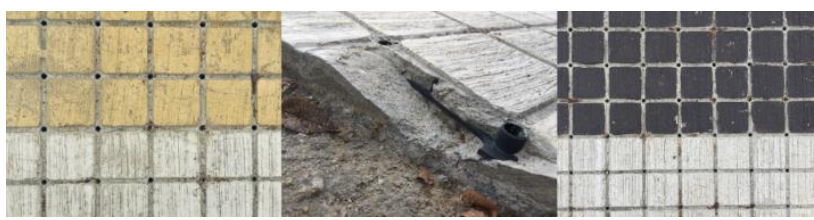

Fig. 1.Permeable pavements in Caohu Park.

Grade score of plant root type: the main trees are Zelkova schneideriana, crabapple, etc. The tree of Grade $\mathrm{A}$ is crabapple. The final grade is: $\mathrm{B}$.

Grade score of water storage capacity of planting roots: most tree species are straight root trees. Sapiumsebiferum and camphor trees ranked at the top. At the end of the list is the Chinese toon tree. The final grade is: $\mathrm{B}$.

Detention pond rating: The dry detention pond in the park has a flood detention volume of about 12,500 cubic meters, an area of about 7,700 square meters, and a flood detention height of more than 2 meters. The final flood detention pool rating is: A. Figure 2 shows the scale of water volume in the park.

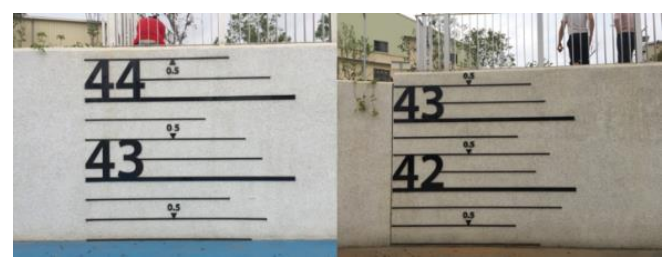

Fig. 2. Park water scale in Caohu Park. 
The wind resistance rating of the tree species: the trees classified as A grade include Qiongya crabapple, Pistacia chinensis, Chinese tallow and camphor trees, and the B grade trees include zelkova and wax trees. The last one is Chinese toon. Qiongya Begonia is located at the air outlet of the park and has good wind resistance; Chinese tallow is located in the water storage area and has water resistance and wind resistance; the zelkova tree in the tree array square has a small crown and is too sparse; toon can be used as a spice, but has weak wind resistance. Qiongya Begonia is located at the air outlet of the park and has good wind resistance; Chinese tallow is located in the water storage area and has water resistance and wind resistance; the zelkova tree in the tree array square has a small crown and is too sparse; toon can be used as a spice, but has weak wind resistance. The wind resistance rating of final tree species is A.

Multi layer planting configuration grade score: The length of the zelkova tree array in the park is $>7 \mathrm{~m}$, lacking middle-level planting; shrubs are rich in hillsides, and most of the grassland is bare or lacking shrubs; part of the green belt lacks mid-high-level planting configuration, and the final multi-level planting configuration is rated : $\mathrm{B}$.

Soil bulk density grade score: The zelkova tree array in the zelkova square area is gravel with good air permeability; the soil of the green belt of the park house is sandy loam, with ordinary air permeability and relatively loose; most of the soil types are loam, with good air permeability and relatively compact, and part of the soil has hardened due to lack of maintenance. The final soil bulk density score is rated : $\mathrm{B}$.

\subsection{Nanyuan Park}

Soil grade score: Loamy soil is the main type in the park, as well as gravel, sandy soil, and sandy loam soil. The trees next to the children's play area are mainly gravel. The soil near the MRT station square and the north gate of the park is sandy soil. Part of the soil is hardened due to the uncovered irrigation system. Therefore, the final soil grade of the park is: $\mathrm{B}$

Lawn ratio and permeable ratio rating: Most of the parks are lawns, without permeable bricks, and mainly rely on lawn drainage and sewer drainage. Although the park does not have permeable facilities, it can still achieve a good permeable effect by virtue of its sufficient lawn space. The final lawn ratio and permeable ratio grade is: A

Permeable pavement rating: Most of the pavements in the park are lawns, most of the pedestrian walkways are impervious interlocking blocks, and individual pavements are gravel and stone slabs. The final permeable pavement rating is: B. Figure 3 shows impervious interlocking block, gravel and slate in Nanyuan Park.

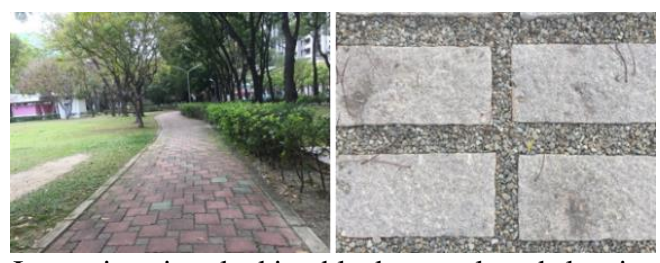

Fig.3. Impervious interlocking block, gravel, and slate in Nanyuan Park.

Grading of planting root system types: The trees in the park mainly include Chinese tallow tree, Ficus lutea, Phoenix tree, Taiwan luan tree, banyan tree, camphor tree, etc.; shrubs mainly include Jiulixiang, Casuarina, etc. There is a group of Liriodendron trees on the north side of the park. The trees of grade A are banyan trees and Taiwan luan trees, and the trees of grade B include camphor trees, etc. The final root system type score grade is: $\mathrm{B}$

Grading of planting root water storage capacity: A few trees in the park are deep-rooted trees. Most of them are taprooted trees and shallow-rooted trees. The A-level tree species include banyan, camphor, tallow and phoenix, which are listed as B-level tree species include Liriodendron tulipifera, Big-leaf Mountain Olive, etc., and C-level tree species include frangipani, etc. The final planting root system water storage rating is: B. Figure 4 shows the current situation of root growth in Nanyuan Park.

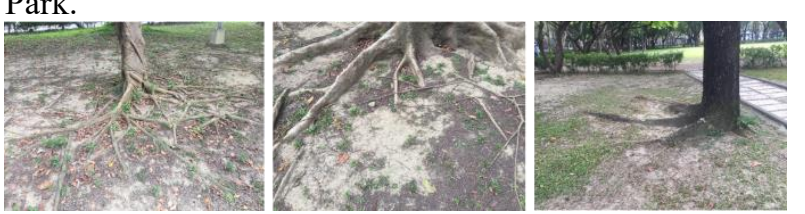

Fig.4. Current situation of root growth in Nanyuan Park.

The wind resistance rating of the tree species: the trees classified as A grade include banyan, camphor tree, tallow tree, and big-leaf mountain olive. The grade B includes phoenix tree, Taiwan luan tree, blackboard tree, etc., and the grade $\mathrm{C}$ has thick bark, Frangipani and so on. The high planting density of Rhizophora japonicus and Chinese tallow tree is good for wind resistance; the phoenix tree has a sparse crown and has just been pruned; Liriodendron tulipifera is wind resistant, but the branches are many and messy; the ultimate wind resistance rating level is: $\mathrm{B}$.

Grading of multi-layer planting configuration: the length of Liriodendron chinense tree array in the park is $>$ $7 \mathrm{~m}$, lack of middle-level bottom planting; lack of middlelevel planting and shrub configuration; lack of planting in children's entertainment area, less shade, and the final multi-layer planting configuration rating is: $\mathrm{C}$.

Soil bulk density grade score: The proportion of loam in the park is relatively high, and most of the soil on the carpet grass grows well, the loam has good air permeability and is relatively compact; some soils gradually harden due to lack of water, and the final soil bulk density grade is: $\mathrm{A}$. 


\subsection{Taichung Park}

Soil grade score: Loam soil is mainly used in the park, as well as sandy soil and sandy loam soil. The grass near the sidewalk and the soil around the square are exposed after repeated trampling by tourists; part of the soil hardens due to lack of water. The final soil score of the park is: B.

Lawn ratio and permeable ratio rating: Most of the parks are lawns, and the permeable area is small. They mainly rely on lawn drainage, sewer drainage and lake water storage. The park has sufficient lawn space and wide lake area, which can achieve good permeable effects. The grading grade of lawn ratio and permeable ratio: A.

Permeable pavement rating: most of the pavement in the park is lawn, a small part is lake and hillside, most of the pavement of pedestrian walkway is impervious interlocking block, individual pavement is wooden board, stone slab, etc. The final permeable pavement rating is: B. Figure 5 shows graded aggregates, impervious interlocking blocks, and boardwalks in the park.

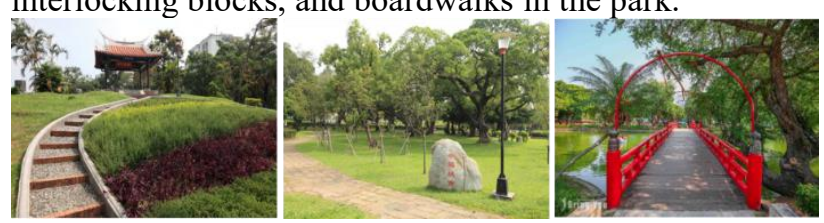

Fig.5. Graded aggregate, impervious interlocking block, and boardwalks in the park.

Grading of planting root system types: The trees in the park mainly include banyan, solanum, camphor, sweetgum, rain peas, elm, Javanese albizia, etc.; shrubs mainly include South American Wedelia, Cigar Flower, etc. Because the park has a long history, the park planted a lot of medium and large banyan trees, and some of the banyan trees form the main scenic tree of the park. The trees of grade A are banyan trees, Taiwan luan trees and camphor trees, and the trees of grade B are Chinese tallow tree and solanum sylvestris. The final root system type is graded as A.

Grading of water storage capacity of planted roots: There are a lot of deep-rooted trees in the park. For example, the deep roots of banyan trees are good for water storage. A few tree species are taprooted trees and shallow-rooted trees. For example, Albizia javanica has short floating roots, which is not conducive to water storage. The tree species classified as A grade include banyan, camphor tree, Chinese tallow tree, wild olive, etc., the tree species classified as B grade include elm elm, Indian red sandalwood, etc., and the tree species classified as grade $\mathrm{C}$ include the rain bean tree, etc. and some new species. The final planting root water storage rating of the tree is: A. Figure 6 shows the banyan tree and the Javanese albizia.

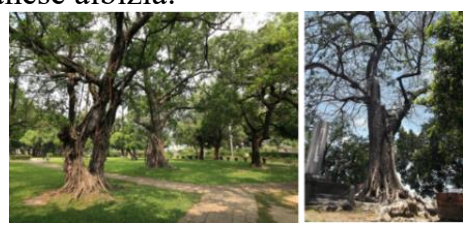

Fig.6. Banyan, Acacia javanica in the park.
Detention basin grade score: The lake area of the park is about 14,000 square meters, and the average depth is 1.4 meters. The final flood detention basin grade is: A.

The wind resistance rating of the tree species: The trees classified as A grade include banyan, camphor tree, tallow tree, wild olive, Liquidambar serrata, etc., and B grade include elm, Indian red sandalwood and so on. Camphor trees and banyan trees have high planting density, deep-rooted trees, and have wind resistance; most of the Javanese Albizia Julibrissin have low leaf density, and the final wind resistance rating of the tree species is: A.

Multi-layer planting configuration grade score: The tree species in the park are diverse; most of the trees are relatively long; there are few plants at the bottom of the banyan group and camphor tree group, lacking middlelevel plants; the lakeside high, middle and low-level plants are abundant, and the final multi-layer planting configuration rating is: $\mathrm{B}$.

Soil bulk density grade score: Loam soil has the highest proportion, good air permeability, and relatively compact; the park has regular maintenance to make plants grow in good condition, indicating that the soil quality is higher; some soils are hardened due to repeated trampling, and the final soil bulk density. The final grading level is: A.

\section{Conclusions and suggestions}

\subsection{Validation results}

Due to the need to compare and analyze the resilience rating scales of three different types of parks, it is necessary to formulate the ratings and various weights in advance. There are a total of 6 items in the comprehensive scoring table for floods, so the weight of each item is about $16.67 \%$, and the scoring table for wind disasters has a total of 4 items, and each item has a weight of $25 \%$. The standards for the overall grade are divided into four grades A, B, C, D, and they are sorted from high to low. The following are the grade scoring standards: A grade: 5 points, $\mathrm{B}$ grade: 3 points, $\mathrm{C}$ grade: 1 point, $\mathrm{D}$ grade: 0 points, the full score of flood damage is 30 points, and the full score of wind damage is 20 points.

Comparison of flood resilience scores in three different types of parks is shown in Table 10. From the summary table of three different types of parks flood resilience scores, it can be seen that the park with the best flood prevention is Taichung Park and slightly better than Caohu Park; disaster prevention parks have more permeable pavements than ordinary parks, and other projects are similar to ordinary parks; The flood prevention capacity of parks with detention ponds is better than that of ordinary parks, and the drainage and water storage capacity is stronger. 
Table 10. Comparison of flood resilience scores in three different types of parks

\begin{tabular}{|c|c|c|c|c|c|}
\hline $\begin{array}{c}\text { Ordinal } \\
\text { number }\end{array}$ & Rating table type & Percentage & $\begin{array}{c}\text { Caohu } \\
\text { Park Grade }\end{array}$ & $\begin{array}{c}\text { Nanyuan } \\
\text { Park grade }\end{array}$ & $\begin{array}{c}\text { Taichung } \\
\text { Park grade }\end{array}$ \\
\hline 1 & Soil grading table & $16.67 \%$ & 3 & 3 & 3 \\
\hline 2 & $\begin{array}{c}\text { Grading table of lawn proportion } \\
\text { and pervious proportion }\end{array}$ & $16.67 \%$ & 5 & 5 & 5 \\
\hline 3 & $\begin{array}{c}\text { Grading table of permeable } \\
\text { pavement }\end{array}$ & $16.67 \%$ & 5 & 3 & 3 \\
\hline 4 & Score table of plant root type & $16.67 \%$ & 3 & 3 & 5 \\
\hline 5 & $\begin{array}{c}\text { Scoring table of water storage } \\
\text { capacity of planting roots }\end{array}$ & $16.67 \%$ & 3 & 3 & 5 \\
\hline 6 & Grading table of detention basin & $16.67 \%$ & 5 & 0 & 5 \\
\hline Total & & $100 \%$ & 24 & 17 & 26 \\
\hline
\end{tabular}

Comparison of wind resilience scores in three different types of parks is shown in Table 11. From the summary table of the flood resilience scores of three different types of parks, it can be seen that the park with the best wind disaster prevention is Taichung Park, which is slightly better than Caohu Disaster Prevention Park. Although Caohu Park is a disaster prevention park, the lack of regular maintenance leads to soil hardening and disaster prevention capabilities. Although there are many trees in Nanyuan Park, it lacks the low- and middle-level planting configuration, which makes it difficult to effectively withstand wind disasters.

Table 11. Comparison of wind resilience scores in three different types of parks

\begin{tabular}{|c|c|c|c|c|c|}
\hline $\begin{array}{c}\text { Ordinal } \\
\text { number }\end{array}$ & Rating table type & Percentage & $\begin{array}{c}\text { Caohu Park } \\
\text { Grade }\end{array}$ & $\begin{array}{c}\text { Nanyuan Park } \\
\text { grade }\end{array}$ & $\begin{array}{c}\text { Taichung Park } \\
\text { grade }\end{array}$ \\
\hline 1 & $\begin{array}{c}\text { Grading table of tree species } \\
\text { and wind resistance }\end{array}$ & $25 \%$ & 5 & 3 & 5 \\
\hline 2 & $\begin{array}{c}\text { Grading table for allocation } \\
\text { of multi layer trees }\end{array}$ & $25 \%$ & 3 & 1 & 3 \\
\hline 3 & $\begin{array}{c}\text { Grading table of multi layer } \\
\text { shrub arrangement }\end{array}$ & $25 \%$ & 3 & 1 & 3 \\
\hline 4 & $\begin{array}{c}\text { Grading table of soil bulk } \\
\text { density }\end{array}$ & $25 \%$ & 3 & 5 & 5 \\
\hline Total & & $100 \%$ & 14 & 10 & 16 \\
\hline
\end{tabular}

Under the assumption that the weight of the criteria is equal, flood and wind resilience scores of three different types of Park are compared as shown in Table 12. From the summary table of three different types of parks flood and wind resilience scores, the park with the highest total score is Taichung Park, followed by Caohu Park, and finally Nanyuan Park. Comparing the data on a 50 points, it can be seen that Taichung Park accounts for The proportion of Caohu Park is the highest, and the proportion of Caohu Park is slightly lower than that of Taichung Park. Nanyuan Park has the lowest score. It can be concluded that the park with the highest degree of resilience is Taichung Park. Taichung Park and Caohu Park have similar resilience and the lowest one is Nanyuan Park.

Table 12. Flood and wind disaster score table

\begin{tabular}{|c|c|c|c|c|}
\hline $\begin{array}{c}\text { Park name / } \\
\text { Types of disasters }\end{array}$ & $\begin{array}{c}\text { Flood resilience } \\
\text { grade score }\end{array}$ & $\begin{array}{c}\text { Wind disaster } \\
\text { resilience grade score }\end{array}$ & Total score & $\begin{array}{c}\text { On the scale } \\
\text { of 50\% }\end{array}$ \\
\hline Caohu Park & 24 & 14 & 38 & $76 \%$ \\
\hline Nanyuan Park & 17 & 10 & 27 & $54 \%$ \\
\hline Taichung Park & 26 & 16 & 42 & $84 \%$ \\
\hline
\end{tabular}

Note: the total score is 50

\subsection{Discussion}

Although the disaster prevention park has a high degree of resilience, it needs continuous maintenance. The plants in the park need to be watered and pruned regularly to keep the plants in a healthy state and maintain the tightness of the soil. The middle and bottom plants need to be strengthened. The configuration of the plant to form a planting group will have better wind resistance and can also form a cool space. The park should be equipped with more permeable pavements to speed up drainage. There should be good water storage facilities and underground water collection systems in the park, such as detention ponds and catch basins. The detention ponds can achieve the effect of water storage. The catch basins can recycle rainwater. The plants selected in the park can take into account the aesthetics. In addition, more attention should be paid to the characteristics of planting and planting such as flood resistance, wind resistance, and easy maintenance.

\subsection{Suggestions}

The weight of the resilience index needs to be adjusted. The flood and wind disaster rating scale needs to continue to be revised and improved. The root type and water storage rating scale of planting roots only consider trees, and shrubs should be studied in the future. It is also needed to continue to improve the impact factors, indicators and evaluation methods of floods and wind disasters.

\section{References}

1. R.E. Smith, J. Dai, S. Yun, "Rapid determination of soil adsorption capacity," Scientific and technological information of soil and water conservation, 21-22+26 (2000)

2. R.F. Carsel, R.S. Parrish, "Developing joint probability distributions of soil water retention characteristics," Water Resources Research, 24(5), 755-769, (1988)

3. K. Wu, R. Zhao, "Soil texture classification and its application in China," ACTA Pedologica Sinica, 56(1), 227-241, (2019)

4. Y. Tian, "Model Constructs of Land Use Change Assessment Integrated from Environmental Conservation and Landscape Ecology: A Case Study of Dadu Tableland," Dissertation of Department of geography Taiwan Normal University, 1-199 (2018)

5. Y. Bai, "Discussion on division of work and construction policy of urban parks in China based on the experience of disaster prevention parks in Japan," (2017)

6. K. Alexander, S. Hettiarachchi, Y. Ou, A. Sharma, "Can integrated green spaces and storage facilities absorb the increased risk of flooding due to climate change in developed urban environments? ," Journal of Hydrology, 579 (2019) 
7. T. Alam, A. Mahmoud, K.D. Jones, J.C. BezaresCruz, J. Guerrero, "A Comparison of Three Types of Permeable Pavements for Urban Runoff Mitigation in the Semi-Arid South Texas, USA," Water, 11(10) (2019)

8. H. Coners, C. Leuschner, "In situ measurement of fine root water absorption in three temperate tree species-Temporal variability and control by soil and atmospheric factors," Basic and Applied Ecology, 6(4), 395-405 (2005)

9. B. Xi, N. Di, Z. Cao, J. Liu, D. Li, Y. Wang, G. Li, J. Duan, L. Jia, R. Zhang, "Characteristics and underlying mechanisms of plant deep soil water uptake and utilization: Implication for the cultivation of plantation trees," Chinese Journal of Plant Ecology, 42(9), 885-905 (2018)

10. Taichung Municipal Government, "To draw up the detailed plan of Taichung city plan [type B Industrial Zone]",https://www.ud.taichung.gov.tw/media/1787 36/73281153730.pdf (2014)
11. D.F. D'Amico, S.M. Quiring, C.M. Maderia, D.B. McRoberts, "Improving the Hurricane Outage Prediction Model by including tree species," Climate Risk Management, 25 (2019)

12. W.K. Clatterbuck, "Storm-damaged Residential Trees: Assessment, Care and Prevention," University of Tennessee and Agricultural Extension Service, (2000)

13. Y. Dong, Y. Huang, G. He, Y. Liu, G. Tan, "Research on the Damage Grade and Wind Resistance of Urban Common Garden Trees in South China," Guangdong Agricultural Sciences, 47(6), 30-38 (2020)

14. C.P. Head, R. Fisher, M. O'Brien, R. Cauthen, "Best management practices for community trees: a technical guide to tree conservation in Athens-Clarke County, Georgia," (2001)

15. C. Quine, M. Coutts, B. Gardiner, G. Pyatt, "Forests and Wind: Management to Minimise Damage," Forestry Commission Bulletin (United Kingdom) (1995) 